Prace Filologiczne. Literaturoznawstwo 10(13) 2020

ISSN 2084-6045

e-ISSN 2658-2503

Creative Commons: Uznanie autorstwa 3.0 PL (CC BY)

DOI: $10.32798 /$ pflit.574

\title{
NIEAGONISTYCZNY CHARAKTER POLSKICH STUDIÓW O LITERATURZE ZAGEADY*
}

\author{
Non-Agonistic Character of Polish Studies of Holocaust Literature
}

\author{
MARTA TOMCZOK \\ Uniwersytet Śląski w Katowicach, Polska \\ E-mail: marta.tomczok@us.edu.pl
}

ORCID: 0000-0001-9512-007X

\section{Abstract}

The purpose of this article is to rethink the thesis claiming a non-agonistic character of Polish Holocaust Studies. The author, using Chantal Mouffe's agonism theory, outlines the model of agonism and then applies it to literary studies and confronts the concept with affirmative humanism of Ewa Domańska. Non-agonistic structure of Holocaust studies in Poland turns out to be their advantage over studies conducted in Europe and in the world, especially those of post-humanistic variety. Two analysed examples of polemics of writers and literary scholars show that the concept of agon should be re-evaluated because it often leads to the weakening of the subject of science and scientific discourse.

Keywords: agonism, affirmation, Holocaust, polemics, literary studies

\section{Streszczenie}

Celem artykułu jest przedyskutowanie tezy o nieagonistyczym charakterze polskich Holocaust studies $\mathrm{w}$ ich aspekcie literaturoznawczym. Autorka, korzystając z teorii agonizmu Chantal Mouffe, zarysowuje model agonizmu, by następnie odnieść go do literaturoznawstwa i skonfrontować z koncepcją humanistyki afirmatywnej Ewy Domańskiej. Nieagonistyczna struktura studiów nad Holokaustem w Polsce okazuje się ich potencjalną przewagą nad studiami prowadzonymi w Europie i na świecie, zwłaszcza w ich odmianie posthumanistycznej. Dwa przeanalizowane przykłady polemik pisarzy i literaturoznawców pokazują natomiast, że pojęcie agonu powinno ulec przewartościowaniu i krytycznej ocenie jako to, które często prowadzi do osłabienia podmiotu nauki oraz dyskursu naukowego.

Słowa kluczowe: agonizm, afirmacja, Zagłada, polemika, literaturoznawstwo

${ }^{*}$ Publikacja artykułu dofinansowana przez Uniwersytet Warszawski. 


\section{Teoria agonizmu a literaturoznawstwo o Zagładzie}

W ocenie Chantal Mouffe współczesna demokracja liberalna potrzebuje przede wszystkim agonu, a zatem formowania społeczeństwa w oparciu o ściśle rozumianą opozycję „my”-,,oni”. Nie chodzi o podtrzymanie sztywnych, binarnych podziałów skutkujących dowartościowaniem większości kosztem mniejszości, ale o rozbudzenie społecznej potrzeby konfliktu. Jego zrozumienie i rozeznanie wymaga od jednostki znalezienia w drugim człowieku nie wroga, lecz przeciwnika, którego idee można niekiedy bezwzględnie zwalczać, respektując jednak zawsze prawo do ich głoszenia.

Polem rozgrywek między oponentami staje się interpretacja rozumiana najszerzej jak to możliwe: jako ocena faktów historycznych, bieżącej polityki, zdarzeń kulturalnych. Zaciekłe konkurowanie o hegemonię, a zatem uczynienie własnej interpretacji interpretacją wszystkich, wynika z przyjętych przez Mouffe założeń dotyczących porządku społecznego. „Rzeczy zawsze mogły mieć się inaczej i każdy porządek jest oparty na wykluczeniu innych możliwości. Każdy porządek zawsze stanowi wyraz partykularnej konfiguracji stosunków władzy"1. Lęk przed ich rekonfiguracją, przekonuje filozofka, nie pozwala teorii liberalnej właściwie się rozwinąć, a co za tym idzie - uznać wagi polityczności. Każda polityczność powstaje wskutek wykluczenia czegoś, nosi więc na sobie ślady dawnej agresji, przemocy czy wykluczenia. Jeśli jednak dobrze rozumiem intencje Mouffe, nie chodzi jej o przekonanie czytelnika do akceptacji mechanizmu wykluczania, ale o uwrażliwienie na fakt, że ustanowienie jednej tożsamości wymaga odrzucenia innej w całości lub w części. Nie przekreśla to jednak możliwości powrotu tego, co wcześniej zostało odrzucone. „Każdy porządek jest zatem podatny na bycie kwestionowanym przez praktyki kontrhegemoniczne, które usiłują dokonać jego dezartykulacji w celu ustanowienia innej formy hegemonii"”.

Model agonistyczny przeważa nad innymi modelami myślenia o polityczności ze względu na swoją otwartość wobec afektów. Ważną rolę odgrywa w nim ludzka namiętność nakłaniająca do konkurowania bądź współzawodniczenia z innymi. Co istotne, Mouffe nie zaznacza, iżby wspomniana „łączliwość” agonizmu z afektami niosła ze sobą ryzyko destrukcji samego modelu. Wiele energii wkłada natomiast w to, aby odróżnić agonizm od antagonizmu i przekonać do zasady, że unikanie współzawodnictwa prowadzi do krótkotrwałych konsensusów, które kończą się wzmocnieniem skrajnej hegemonii.

${ }^{1}$ Ch. Mouffe, Agonistyka. Polityczne myślenie o świecie, tłum. B. Szelewa, Warszawa 2015, s. 18.

${ }^{2}$ Ibidem. 
W demokracji pluralistycznej spory co do interpretacji wspólnych zasad etyczno-politycznych są zatem nie tylko uzasadnione, ale wręcz konieczne. [...] Gdy agonistyczna dynamika pluralizmu ulega zahamowaniu ze względu na brak demokratycznych form identyfikacji, namiętności nie znajdują demokratycznego ujścia. Powstaje grunt dla różnych form polityki artykułowanej wokół esencjalistycznych tożsamości typu nacjonalistycznego, religijnego i etycznego, a także dla nasilenia konfrontacji z nienegocjowalnymi wartościami moralnymi, ze wszystkimi manifestacjami przemocy, jakie konfrontacje te mogą ze sobą nieść3.

O ile łatwo zrozumieć konsekwencje odrzucenia modelu agonistycznego w polityce, o tyle trudno pojąć, czym może skutkować podobny gest w przypadku literaturoznawstwa dotyczącego Zagłady ${ }^{4}$. W niniejszym artykule zamierzam przyjrzeć się polemikom toczącym się w ostatnich kilkunastu latach wokół publikacji naukowych i literatury wspomnieniowej związanej z Zagładą. Terenem wzmożonej obserwacji będzie współczesne literaturoznawstwo polskie. W moim przekonaniu - które formułuję w postaci tezy - stroni ono od agonizmu, popadając w różnego rodzaju antagonizmy, co skutkuje zachwianiem polityki konsensualności i istnieniem wielu praktyk hegemonicznych. W zbliżony sposób o konsekwencjach pozornego ładu w studiach historycznych pisała Joanna Tokarska-Bakir, twierdząc, że dopóty Sąsiedzi Jana Tomasza Grossa nie przeorali społecznej świadomości historyków, dopóki panująca w ich pracach dotyczących Zagłady pozytywistyczna neutralność miała charakter „sadyzmu społecznego", w rozumieniu Roberta Mertona oznaczającego uformowanie struktur społecznych w taki sposób, aby systematycznie powodowały one u określonych osób ból i cierpienie ${ }^{5}$.

Źródeł nieagonistycznej struktury studiów nad literaturą Holokaustu nie należy wiązać z takimi mechanizmami jak opisany wyżej. Ich bliska relacja ze studiami historycznymi na temat Zagłady, uformowanymi w zasadzie prawie wyłącznie na sporach o tak fundamentalnym znaczeniu jak spór o Sąsiadów, powoduje, że trudno nie zapytać o przyczyny zachowania przez literaturoznawstwo pozornej neutralności. Jednym z jej przykładów może być, skłaniająca do wspomnianej konfrontacji, obserwacja publikacji naukowych poświęconych oddziaływaniu polemik prowadzonych wokół pracy Grossa na współczesne narracje literackie o Zagładzie. Skala tego zjawiska nie została dotąd uchwycona ani zadowalająco opisana pomimo pojawienia się pojęcia „narracje pojedwabieńskie”,

${ }^{3}$ Ibidem, s. 23.

${ }^{4}$ Wybieram to pole badań jako najbliższe moim zainteresowaniom. Agon interesuje mnie przede wszystkim jako jedna $\mathrm{z}$ możliwych wersji tożsamości studiów nad Zagładą, a nie jako kategoria ważna sama w sobie.

${ }_{5}^{5}$ J. Tokarska-Bakir, Nowa polska szkoła historyczna albo sabat antypolskich czarownic w Paryżu, https://www.academia.edu/38512291/Nowa_polska_szko\%C5\%82a_historyczna_albo_ sabat_antypolskich_czarownic_w_Pary\%C5\%BCu (d.d. 16.02.2019). 
które miało stanowić okazję do porównania praktyk w obrębie obu dyscyplin ${ }^{6}$. W tym samym czasie spór historyków, publicystów, politologów, socjologów czy filozofów doczekał się kilku niezwykle rzetelnych i pomysłowych analiz?

Nieagonistyczna struktura literaturoznawstwa poświęconego Zagładzie, jak będę starała się pokazać dalej, zachowuje pozory agonistyczności. W rzeczywistości jednak zastępuje nimi zupełnie inne problemy, takie jak brak kompleksowych badań poświęconych estetyce reprezentacji Holokaustu, przesadne przywiązanie do zwrotu etycznego czy niewolniczą wręcz zależność od badań materiałowych. Chcąc dobrze uchwycić istotę problemu, posłużę się dwoma przykładami polemik. Pierwszy pochodzi z 2002 roku i dotyczy publikacji szkicu Pokolenie Szoa przez Henryka Grynberga, dyskredytującego m.in. Czarne sezony Michała Głowińskiego, a następnie reakcji Jacka Leociaka. Drugi przykład tworzą recenzja polemiczna Danuty Szajnert na temat monografii Pawła Wolskiego Tadeusz Borowski - Primo Levi. Prze-pisywanie literatury Holocaustu oraz odpowiedź na nią autora. W obu przypadkach spór zawiązuje się między badaczami a literaturą, a dopiero później pomiędzy samymi badaczami. Rola oponenta zostaje zminimalizowana i sprowadzona do kogoś w rodzaju pośrednika między interpretatorem a tekstem, co powoduje, że model agonizmu zaproponowany przez Mouffe ulega daleko posuniętym modyfikacjom i przypomina raczej sieć niejasnych zależności między wchodzącymi w dialog obiektami niż pojedynek adwersarzy. Widać to przede wszystkim $w$ drugim z przykładów.

\section{Krótkie wprowadzenie}

Trudno zrozumieć nieagonistyczny charakter polskich studiów na temat literatury Zagłady bez, chociażby krótkiego, wyjaśnienia roli agonizmu w studiach światowych. Wytłumaczenia wymaga także obserwowany tutaj niedługi odcinek czasowy (lata 2002 i 2016). Dyskusje wokół tego, jak pisać, i czy w ogóle pisać o ludobójstwie Żydów, stanowią najważniejsze źródło długiego i niejednorodnego projektu literaturoznawczego, który stworzono po wojnie. W zasadzie miał on wpływ na każdą pojedynczą twórczość poetycką i prozatorską: od Paula Celana, przez Adolfa Rudnickiego, po Raymonda Federmana. Praktyka literacka pokazuje, że refleksje tego typu były obecne już w literaturze dokumentu osobistego, a nazywanie ich polemikami czy sporami wynika przede wszystkim z potrzeby prowadzenia przez autorów dialogu z samymi sobą i wyjaśnienia wątpliwości co do tego, jak powinno wyglądać bycie pisarzem-świadkiem.

${ }^{6}$ M. Tomczok, Czyja dzisiaj jest Zagłada? Retoryka - ideologia - popkultura, Warszawa 2017, s. $268-316$.

${ }^{7}$ P. Dobrosielski, Spory o Grossa. Polskie problemy z pamięcia o Żydach, Warszawa 2017; M. Nowicka-Franczak, Spór o książki Jana Tomasza Grossa, Warszawa 2017; P. Forecki, Po Jedwabnem. Anatomia pamięci funkcjonalnej, Warszawa 2018. 
Najbardziej wpływowy z takich sporów, o zdecydowanie najwyrazistszym profilu i największym rozmachu, spór Theodora W. Adorno z Paulem Celanem, w znacznym stopniu ukształtował literaturę europejską. Według Anity Jarzyny i Katarzyny Kuczyńskiej-Koschany jego oddźwięk w Polsce był jednak zdecydowanie za słaby i nie rozwinął się w żadną osobną narrację, co poskutkowało reorientacją studiów nad Zagładą w kierunku psychologii zamiast filozofii:

[...] na gruncie polskim nigdy nie odbyła się dyskusja na miarę sporu Paula Celana z Theodorem W. Adorno, sporu, w następstwie którego trwale ustaliła się poznawcza ranga poezji jako równoprawnej partnerki dociekań filozoficznych. Symptomatyczne, że w naszym kręgu językowym recepcja tej debaty przebiegała w innym kierunku niż w humanistyce niemieckojęzycznej i nie poskutkowała metodologicznymi przewartościowaniami. Niewykluczone, że wpływ na powstanie owej luki miała raczej psychologiczna (szkoła Antoniego Kępińskiego i Marii Orwid; badania nad syndromem posttraumatycznym) niż filozoficzna orientacja polskiej poholokaustowej refleksji humanistycznej w pierwszych latach po drugiej wojnie światowej, a potem konsekwentna polonizacja Zagłady w dyskursie publicznym i edukacji w kolejnych dekadach. Dopiero lata 80. przynoszą tu zmianę - cezurę stanowią rozmowy Hanny Krall z Markiem Edelmanem ${ }^{8}$.

Przypomnijmy w skrócie przebieg tego sporu. W 1955 roku Adorno zanotował zdanie, że „po Auschwitz pisanie wierszy to barbarzyństwo”. Łączono je, ku niezadowoleniu Celana, z Todesfuge. Wyraz temu twórca dał w opowiadaniu Rozmowa w górach z 1959 roku, gdzie pośród odwołań do wielu różnych tekstów (m.in. Georga Büchnera czy Friedricha Nietzschego) przywołał także wyobrażenie rozmowy między sobą a autorem Minima moralia, która nigdy nie miała miejsca. Podstawą tego wyobrażenia stała się wspólna żydowska tożsamość Adorna i Celana. Jak wyjaśnia John Felstiner:

Podpisując nadbitkę Gespräch im Gebirg, Celan wspominał Sils-Maria, „gdzie miałem spotkać się z panem profesorem Adorno, o którym sądziłem, że jest Żydem”. Pisząc to, miał na uwadze, iż Theodor Wiesengrund odrzucił żydowskie nazwisko swego ojca, przyjmując katolicie nazwisko matki, Adorno. Kiedy Adorno i Celan w końcu się spotkali, ten pierwszy powiedział, iż poeta powinien był zostać dłużej w Sils, a wówczas spotkałby „prawdziwego Dużego Żyda, Gershoma Scholema”, którego praca nad przywracaniem żydowskiej tradycji mistycznej zaczynała oddziaływać na Celana ${ }^{10}$.

${ }^{8}$ Fragment jest częścią zaproszenia do piątego numeru rocznika „Narracje o Zagładzie”, który zgodnie z pomysłem obu badaczek będzie poświęcony poezji i Zagładzie i ukaże się w 2019 roku: http://www.noz.us.edu.pl/planowane-numery/ (d.d. 17.03.2019).

${ }^{9}$ Zgodnie z ustaleniami Johna Felstinera, biografa i interpretatora twórczości Celana, słowa pochodzą z Kulturkritik und Gesellschaft, napisanych w 1949 roku w USA i opublikowanych jako osobny tekst w 1951 roku. W 1955 roku słowa te stały się częścią wydanej w Berlinie pracy Prismen. Vide J. Felstiner, Paul Celan. Poeta, ocalony, Żyd, tłum. M. Tomal, M. Tomal, red. P. Paziński, Budapeszt 2010, s. 195.

${ }^{10}$ Ibidem. 
Dopiero w latach sześćdziesiątych, gdy Celan porzucił poezję muzyczną (jak sam nazywał wiersze w rodzaju Fugi śmierci) i napisał Aschrei, Adorno odwołał swój słynny sąd o nieprzystawalności opisu poetyckiego do tragedii wojennej Żydów i w ramach ugody przyznał: „Wieloletnie cierpienie ma takie samo prawo do uzyskania wyrazu, jak torturowani do krzyku, dlatego nie powinno się chyba twierdzić, że po Auschwitz nie mogą powstawać wiersze"11. Jak pisała Kuczyńska-Koschany, za sprawą tego gestu widać, jak filozof ustępuje poecie. Adorno „nie chce dyktować warunków czytania świata po Zagładzie komuś tak wrażliwemu jak Celan, prowadzi spór tak długo, aż widzi, że jego argumenty są słabsze, uczciwie" 12 .

Rezonans idei ukształtowanych w tym sporze, a oscylujących między milczeniem i mówieniem, objął w Polsce przede wszystkim obszar problematyki literatury, a nie refleksji metaliterackiej. Jednak zdaniem autorek koncepcji poetyckiego numeru „Narracji o Zagładzie” nie przyczynił się on do powstania sporu o tematyce czy charakterze zbliżonych do tego, który rozgorzał między Adornem a Celanem. Dopiero w wydanych po 1989 roku pracach literaturoznawców takich jak Aleksandra Ubertowska, Bartłomiej Krupa czy Paweł Wolski pojawiły się rozległe nawiązania do wspomnianej polemiki. Uległa ona jednak, zwłaszcza w pracach Krupy i Wolskiego, daleko idącym przekształceniom i została sprowadzona właściwie do rekonstrukcji zmiany stanowiska autora Prismen w odniesieniu do możliwości świadczenia przez literaturę o Zagładzie ${ }^{13}$. A dokładniej - do wskazania różnic między poszczególnymi wypowiedziami myśliciela na ten temat. Ze wspomnianych rekonstrukcji zupełnie zniknęło nazwisko Celana, co należy wiązać, po pierwsze, $z$ trudnością odtworzenia opisanej historii ze źródeł niemieckojęzycznych oraz, po drugie i najważniejsze, z jej znikomym znaczeniem dla polskiej refleksji o Zagładzie. Dalekie i spłaszczone echo tej dyskusji wprawdzie nigdy nie przestało rezonować w Polsce, nie przeobraziła się ona jednak w żaden kolejny spór poza przypominaniem ornamentów, a niekiedy wręcz powtarzaniem komunałów.

Jak wynika z pracy Krupy Opowiedzieć Zagładę..., literaturoznawstwo polskie znalazło jednak narrację suplementarną. Odtworzenie sporu o pryncypia pisania literatury świadectwa za pomocą odpowiednio skomponowanej opowieści o stanowiskach obrońcy dokumentu, Berela Langa, i zwolennika

${ }^{11}$ T. Adorno, Negative Dialektik. Meditationen zur Metaphysik, Frankfurt 1966, s. 353. Cit. per J. Felstiner, Paul Celan. Poeta..., s. 446.

${ }^{12} \mathrm{Z}$ korespondencji prywatnej pochodzącej z 16.03.2019 r. Vide K. Kuczyńska-Koschany, Wsje poety Żydy. Antytotalitarne gesty poetyckie i kreacyjne wobec Zagłady oraz innych doświadczeń granicznych, Poznań 2013, s. 99.

${ }^{13}$ B. Krupa, Opowiedzieć Zagładę. Polska proza i historiografia wobec Holocaustu (1987-2003), Kraków 2013, s. 18. 
świadectwa figuralnego, Haydena White'a, stało się uzasadnieniem także i dla wyborów rodzimej humanistyki, szczególnie tej zajmującej się prozą. Znacznie większy wpływ pism White'a niż Adorna, poparty nie tylko licznymi do nich nawiązaniami, ale i całą serią analiz historyków i historyków literatury ${ }^{14}$, wynikał zapewne z różnic między trudną, fragmentaryczną i do pewnego stopnia ogólnikową refleksją przedstawiciela „szkoły frankfurckiej” a praktycznym wymiarem nauk White'a, dających się zastosować do analizowania także i polskiej literatury.

$\mathrm{Z}$ całą pewnością należy powiedzieć o jeszcze jednej cesze polskiego literaturoznawstwa, usprawiedliwiającej unikanie praktyk agonistycznych. Postawieni wobec faktu, że zbiór polskich narracji o Zagładzie jest najzasobniejszym zbiorem na świecie, badacze prawdopodobnie nigdy nie zwątpili w istotę swoich działań, zajęło ich natomiast tego zbioru poznawanie, porządkowanie i układanie. Dlatego szereg najważniejszych, przekrojowych monografii, na czele z pracami Jacka Leociaka, Sławomira Buryły, Katarzyny Kuczyńskiej-Koschany, Aleksandry Ubertowskiej, Justyny Kowalskiej-Leder, Anny Mach czy Małgorzaty Wojcik-Dudek, ma w dużej mierze charakter materiałowy i nie skupia się na ideach dalekich od praktyki badawczej tekstu, niezaprzeczalnie dowodzącej, że literatura Zagłady istnieje i należy „coś” z tym faktem zrobić.

Konsekwencją tej sytuacji jest ograniczona ilość polemik literaturoznawczych niepozostawiająca badaczowi agonistyki większego wyboru. W zaproponowanych tutaj przykładach można jednak zobaczyć narracje do pewnego stopnia symboliczne, choć słabo związane z kontekstami społeczno-politycznymi literatury. Pierwsza $\mathrm{z}$ polemik dotyczy nie tego, co specyficzne w literaturze o Zagładzie, ale najbardziej typowych właściwości literatury jako takiej: oryginalności i epigoństwa. Druga z dyskusji - przy wszystkich zawiłościach z nią związanych - w zasadzie nie różni się od pierwszej. Także i jej tematem przewodnim są oryginalność badawcza i epigonizm wobec czyichś poglądów. Warto przyjrzeć się obu polemikom bliżej po pierwsze po to, aby upewnić się, czy ich tematyka została właściwie określona i w rzeczywistości ma tak elementarny charakter. Druga kwestia, która powinna nas zainteresować, wiąże się z wątkami pobocznymi obu dyskusji. W myśl powziętych tu założeń to właśnie one są ważniejsze od jawnie dyskutowanych problemów.

${ }^{14}$ Cf. trzy antologie artykułów White’a przygotowane przez Ewę Domańską: H. White, Poetyka pisarstwa historycznego, red. E. Domańska, M. Wilczyński, Kraków 2000; H. White, Proza historyczna, red. E. Domańska, Kraków 2009; H. White, Przeszłość praktyczna, red. E. Domańska, Kraków 2014; J. Muchowski, Polityka pisarstwa historycznego, Warszawa-Toruń 2015. 


\section{Przykład pierwszy: polemika między Michałem Głowińskim, Henrykiem Grynbergiem a Jackiem Leociakiem}

Za decyzją, aby rozpisać tę dyskusję między trzy, a nie dwa podmioty, które faktycznie brały w niej udział, stoi przekonanie, że w szkicu Pokolenie Szoa, ogłoszonym w „Odrze” w 2002 roku, Grynberg potraktował Głowińskiego jako ważnego oponenta. Postanowił jednak ukryć ten wybór za oskarżeniami pisarza o epigonizm, czyniąc z autora Marcowego gadania kogoś o mniejszym znaczeniu niż to, które nadane mu zostało w niejawnym wymiarze dyskusji. Głowiński okazał się „winien” zapożyczeń z prozy Idy Fink, Hanny Krall i samego Grynberga. Większość z nich miała jednak charakter często spotykanych w literaturze o Zagładzie wyrażeń i zwrotów, za pomocą których świadkowie zwykli opisywać okupacyjną rzeczywistość, pobyt w getcie, ukrywanie się po aryjskiej stronie, szmalcowników itp. Drugi rodzaj „błędów” wskazanych przez Grynberga w Czarnych sezonach odnosił się do uwag bohatera-narratora na temat zapominania, niepamięci, mechanizmów pamiętania. Zdaniem autora Ekipy Antygona, po pierwsze, Głowiński za późno podjął decyzję o notowaniu wspomnień, pozwalając im w większości „ulecieć” i „rozpłynąc się” (co miałoby mieć związek ze wspomnianym epigonizmem). Po drugie, programowo uchylił się on od pisarskiego obowiązku ${ }^{15}$ polegającego na zaświadczaniu prawdzie, a nie opowiadaniu o kłopotach z pamięcią. Trzeci rodzaj „błędów”, o których wspomniał Grynberg, czytając prozę Głowińskiego, dotyczy wyjaśnień odautorskich, występujących w niej w nadmiarze (podczas gdy „dobra proza unika [takich - M. T.] wyjaśnień [...], sama się wyjaśnia"16). Podsumowaniem serii zarzutów pod adresem Czarnych sezonów Grynberg uczynił wyznanie:

Rezultatem nie jest jednak autowiwisekcja, lecz opowieść postrzępiona, niezdyscyplinowana, potwierdzająca, że na starość zachowują się w pamięci oderwane fragmenty, które trudno ułożyć w całość. Prawdziwy pisarz umie sobie z tym poradzić (udowodniła to m.in. Ida Fink w swojej opowieści Podróż $)^{17}$.

Liczne komentarze krytyki potwierdziły, że obserwacja Grynberga, urastająca do rangi zarzutu, doczekała się - wbrew intencjom adwersarza, a nawet niezależnie od nich - szczególnego uznania i pozwoliła postawić tę twórczość m.in. obok prozy Georgesa Pereca, w podobny sposób co Głowiński opisującego rolę niepamiętania w odtwarzaniu rzeczywistości okupacyjnej i żydowskiej tożsamości. Inaczej na tę sytuację zareagował Leociak, który wykazał absurdalność

${ }^{15}$ H. Grynberg, Pamiętnik, Warszawa 2011, s. 584-586. Zapiski oznaczone w pamiętniku nazwą „McLean, luty 2002 (patrz „Odra”, 4/2002)” zostały wcześniej opublikowane we fragmentach w miesięczniku „Odra” jako Pokolenie Szoa, „Odra” 2002, nr 4, s. 37-49.

${ }^{16}$ H. Grynberg, Pamiętnik, s. 586.

${ }^{17}$ Ibidem, s. 588. 
stawianych w podobnym tonie zarzutów: „Grynberg dyskredytuje Głowińskiego jako świadka holocaustu. Jakby nie zauważał jego obecności w getcie warszawskim i na Umschlagplatzu. Obecności realnej, a nie wyobrażonej, nie empatycznej jedynie, ale faktycznej" ${ }^{18}$. Zdaniem autora Doświadczenia granicznego największe zastrzeżenie musi budzić fakt, że Głowiński i Grynberg dzielą doświadczenie Zagłady. Nie można zatem dopuścić do uznania za prawdę insynuacji, jakoby Zagłada była doświadczeniem obu ich dzielącym, a wręcz czyimś doświadczeniem indywidualnym, na które jedni świadkowie mają copyright, a inni nie ${ }^{19}$. Gdyby chciało się przedstawić przedmiot sporu Leociaka z Grynbergiem w języku teorii literatury, należałoby powiedzieć, że autor Prawdy nieartystycznej nie rozpoznał wspólnego wszystkim narracjom o Zagładzie źródła, jakim jest topika holokaustowa ${ }^{20}$. Rzeczywiste obrazy $\mathrm{z}$ czasem stają się zleksykalizowanymi i spetryfikowanymi wyobrażeniami należącymi do wspólnego słownika świadków i postświadków (czy raczej, jak napisała Anna Mach, świadków świadectw ${ }^{21}$ ). Upominanie się o prawa autorskie ${ }^{22}$ nie ma większego sensu.

Najciekawsza w całym sporze wydaje się odpowiedź Grynberga Leociakowi: „Nie jestem »właścicielem «, ale bodajże najstarszym pod względem stażu polskim pisarzem tej tematyki i zależy mi na utrzymaniu poziomu" ${ }^{23}$. Czarne sezony Głowińskiego stają się obiektem ataku Grynberga głównie dlatego, że nie trzymają poziomu, są - zdaniem autora Uchodźców - słabą artystycznie prozą, pełną pustych fraz i powtórzeń. Nie jest istotne, że są także świadectwem. Od świadectwa Grynberg oczekuje niewiele, może ono być artystycznie mierne, dobra musi być tylko literatura piękna ${ }^{24}$. Niezależnie od tego, czy przedstawione w ten sposób stanowisko jakkolwiek wiąże się ze sporem Celana z Adornem, warto mieć na uwadze zupełnie co innego niż fakt, że Grynberg jako jeden z nielicznych ocalonych z Zagłady tak wysoko stawia prozę artystyczną. Czyni to tylko dlatego, że znalazł godnego siebie przeciwnika i za sprawą jego, zupełnie odmiennej, literatury buduje swoją agoniczną tożsamość, jak gdyby inaczej nie umiał osiągnąć hegemonii. W akcie „zerwania” z Głowińskim jako prekursorem wyraźnie widać opisany przez Harolda Blooma lęk przed wpływem, a wraz z nim

${ }^{18}$ J. Leociak, Grynberg niebanalnie o Gtowińskim, „Odra” 2002, nr 4, s. 64.

${ }^{19}$ Ibidem, s. 66.

${ }^{20} \mathrm{Na}$ temat topiki Zagłady pisał m.in. S. Buryła, Wokót Zagłady. Szkice o literaturze Holokaustu, Kraków 2016, s. 49-82. Zagadnieniu temu poświęcono także część numeru drugiego „Narracji o Zagładzie” z 2016 r. z artykułami m.in. Sławomira Buryły, Justyny Kowalskiej-Leder, Katarzyny Kuczyńskiej-Koschany i Pawła Wolskiego.

${ }^{21}$ A. Mach, Świadkowie świadectw. Postpamięć Zagłady w polskiej literaturze najnowszej, Warszawa-Toruń 2016.

${ }^{22}$ J. Leociak, Grynberg..., s. 66.

${ }^{23}$ H. Grynberg, Mój krytyk za dużo wyczytat, „Odra” 2002, nr 6, s. 67.

${ }^{24}$ Ibidem. 
cały szereg mechanizmów składających się na negocjowanie oryginalności przez poetę odcinającego się od inspirującego go autora ${ }^{25}$. Agonistyczny błąd polega, zdaniem badacza, na nienawiści do prekursora-przeciwnika ${ }^{26}$, unikaniu bezpośrednich relacji i wypieraniu wszystkich możliwych związków między inspirującym się i jego źródłem. Agon potrzebny jest Grynbergowi jedynie po to, aby umocnić dominację, która w tej sytuacji objawia całą swoją pozorność, czy wręcz słabość, i zmienia się we własne przeciwieństwo, czyli antagonizm.

Co oznacza omówiony przykład agonizmu dla studiów nad literaturą Zagłady? Po pierwsze uświadamia, że nie jest ona obszarem autonomicznym, lecz rządzi się tymi samymi prawami co wszystkie pozostałe rodzaje literatury. Po drugie pokazuje, że także i tutaj dominuje język recenzenckich ocen, pochopnych zaszeregowań i nietrwałych rozpoznań. Spór między Leociakiem a Grynbergiem, do którego włączony został Głowiński jako autor Czarnych sezonów, w istocie przypieczętowuje ważność - budzącej wiele wątpliwości - literatury Zagłady i wspierającego ją literaturoznawstwa. Spierają się ze sobą nie dwaj uczeni, ale uczony z pisarzem i pisarz z uczonym-pisarzem. Potwierdza to jedynie swobodę panującą wewnątrz dyskursu o Zagładzie, ale i pewną niefrasobliwość całej dyskusji wywołanej skandalicznym, jak napisała Tokarska-Bakir, zachowaniem Grynberga: że trzeba bronić swojego prawa do istnienia przed czyimś prawem do pierwszeństwa ${ }^{27}$.

\section{Przykład drugi: polemika między Danutą Szajnert a Pawłem Wolskim}

Drugi z przypadków obejmuje dwa wystąpienia ogłoszone na łamach „Tekstów Drugich" w 2016 roku w następstwie publikacji monografii Wolskiego poświęconej twórczości Tadeusza Borowskiego i Primo Leviego w kontekście literatury Zagłady. Wydrukowana jako pierwsza, wyjątkowo obszerna recenzja łódzkiej badaczki zawiera przede wszystkim rzetelne omówienie wspomnianej książki: przypomina jej główną tezę, założenia, treść poszczególnych rozdziałów, ramy teoretyczne. Są to sprawy elementarne, ale ważne, ponieważ z meandrycznego ${ }^{28}$ wywodu Wolskiego nie da się ich łatwo wyczytać, co w pewien sposób także irytuje autorkę. Spiera się ona jednak przede wszystkim ze skłonnością Wolskiego do „prze-pisywania” słów badaczy Zagłady i przypisywania im treści oraz

${ }^{25}$ H. Bloom, Lęk przed wptywem. Teoria poezji, thum. A. Bielik-Robson, M. Szuster, Kraków 2002, s. 57-59.

${ }^{26}$ Trzeba pamiętać, że Głowiński jest w tej sytuacji prekursorem „dziwnym”, sam bowiem mógłby traktować literaturę Grynberga jako źródło inspiracji (o ile zwątpi się w insynuacje tego ostatniego). Jego „prekursorstwo” i „ojcostwo” to w istocie określenia wpływu na siebie twórczości rówieśniczej (obaj pisarze urodzili się w 1934 r.).

${ }^{27}$ J. Tokarska-Bakir, Skandalista Henryk Grynberg, ,ResPublica Nowa” 2003, nr 6, s. 90-101.

${ }^{28}$ Określenie to pojawia się także we wspomnianej recenzji. Vide D. Szajnert, O prze-pisywaniu, „Teksty Drugie” 2016, nr 1, s. 240. 
intencji, których nie zawierają. Oto niektóre z „prze-pisanych” stanowisk: „Próbuje [Wolski - M. T.] nas przekonać, że Alina Molisak włączyła prozę Borowskiego i kilku innych nieżydowskich pisarzy do literatury »mówiącej o Szoa, określeniu rzadziej jeszcze niż Holocaust łączonym z nieżydowskim doświadczeniem wojny«”29. Albo: „odpowiedzialnymi za [...] własną tezę uczynił [Wolski - M. T.] Lawrence'a Douglasa i Tomasza Majewskiego [...]. Teza ta dotyczyła literackich wzorców »wyrażania niewyrażalnego«, z których rzekomo korzystali ocalali zeznający w procesach przeciwko zbrodniarzom [...]. Jednakże artykuły, na które powołał się autor książki, nie dają podstaw do takich wniosków"30.

Bardzo podobną konkluzję można wysnuć z innego przykładu, niewspomnianego przez recenzentkę. Dotyczy on omówienia pracy Michała Januszkiewicza Horyzonty nihilizmu. Gombrowicz, Borowski, Różewicz ${ }^{31}$, z której Wolski, po pierwsze, błędnie wyczytuje dialog Borowskiego z tezami prac Romana Ingardena (zawartymi nie, jak podaje autor, w Prawdzie i etyce dzieta sztuki, ale w Studium literackim $w$ Nieborowie ${ }^{32}$ ). Po wtóre, powtarzając Januszkiewicza, ustawia Borowskiego w opozycji do György Lukacsa, nie porównawszy propozycji interpretacyjnych uczonego ani z oryginałem, ani z innymi, chyba znacznie lepiej znanymi wówczas autorowi Kamiennego świata koncepcjami realizmu ${ }^{33}$. W wyniku takich działań, jak zauważa Szajnert, monografia szczecińskiego badacza staje się polem różnego rodzaju rzeczywistych i potencjalnych sporów. „Wolski tak konstruuje swój wywód, jakby musiał zmagać się z jakimiś oponentami. Dlaczego zatem nie wskazał żadnego współczesnego badacza, zajmującego się literaturą Zagłady, który kwestionuje literackość świadectw tych dwóch twórców?"34 W przeciwieństwie do Grynberga autor Wstrętu i Zagłady wzmacnia siłę podmiotu swojego dyskursu za pomocą całej sieci różnic, których istnienie wykazuje między sobą a innymi podmiotami humanistyki. Owe różnice zaznacza jednak w sposób zniuansowany i subtelny (co inna recenzentka określiła mianem „przenikliwości interpretacyjnej”35). Może to jednak sprawiać wrażenie, jakby w pracy stworzonej wokół dość osobliwego przekonania o istocie literatury Zagłady zabrakło najważniejszego - wskazania autora (autorów) dekonstruowanej tezy.

${ }^{29}$ Ibidem, s. 232.

${ }^{30}$ Ibidem.

${ }^{31}$ M. Januszkiewicz, Horyzonty nihilizmu. Gombrowicz, Borowski, Różewicz, Poznań 2009.

${ }^{32}$ T. Borowski, Krytyka, w: idem, Pisma w czterech tomach, red. T. Drewnowski, J. Szczęsna, S. Buryła, Kraków 2005, s. 184-210.

${ }^{33}$ P. Wolski, Tadeusz Borowski - Primo Levi. Prze-pisywanie literatury Holocaustu, Warszawa 2013, s. 124-128.

${ }^{34}$ Ibidem, s. 239.

${ }^{35}$ A. Ubertowska, Pawet Wolski, Tadeusz Borowski - Primo Levi. Przepisywanie literatury Holocaustu, Wydawnictwo IBL PAN, Warszawa 2013, 362 s., „Zagłada Żydów. Studia i Materiały” 2015, nr 11, s. 647. 
W swojej odpowiedzi Danucie Szajnert Wolski, zamiast odnieść się do poszczególnych części jej krytyki, przypisuje swojej polemistce argument, który uznaje za najbardziej dotkliwy (zarzut o „prze-pisywanie”).

Nie jest to praktyka zaskakująca, tyle że zamiast, jak de Man, szukać pominięć, przesunięć itp. w czytanym przez siebie tekście, badaczka pomija własne w czytaniu tych odczytań pominięcia, przeinaczenia i przesunięcia, fikcjonalizujące (w sensie opowiadania okoliczności prawdopodobnych, a nie nieznanych) porządek mojego wywodu ${ }^{36}$.

Zdaje się, że zarówno Wolski, jak i Szajnert - która funkcjonuje w jego recenzji w charakterze alegorii czytania literatury jako czytania czyichś komentarzy, opracowań i interpretacji, nie zaś samego tekstu - spotykają się w polemice z bardzo zbliżonymi upodobaniami. Oboje, czego próbuje dowieść autor Wstrętu i Zagłady..., widzą literaturę Zagłady przez pryzmat komentarzy do niej, ale w przeciwieństwie do Wolskiego Szajnert nie ujawnia, że wie, co widzi. Jakie są tego przyczyny? Wydaje się, że Szajnert daje wyraz innemu niezadowoleniu niż to, które przypisuje jej Wolski. Irytuje ją gęsta sieć cytatów i parafraz czyichś stanowisk, którą napotyka w Tadeuszu Borowskim - Primo-Levim... $\mathrm{Z}$ kolei autor monografii tak właśnie wyobraża sobie pisanie o Zagładzie. Własne stanowisko tworzy się - jego zdaniem - w (agonicznej) odpowiedzi na stanowiska cudze. Jest to konsekwencja przyjętego przez Wolskiego założenia o autonomizacji i instytucjonalizacji dyskursu o Zagładzie, opierającego się na przekonaniu, że kategorie i pojęcia takie jak niewyrażalność, wyjątkowość, kicz holokaustowy czy pornografizacja narracji o Zagładzie są charakterystyczne wyłącznie dla tej problematyki. A przecież wcale tak nie jest: wiele z nich ma nieustabilizowane znaczenie i wymaga ujęć porządkujących (jak kicz), łączy się z określonymi teoriami (jak postmodernizm w przypadku wyjątkowości i niewyrażalności) i często występuje także w odniesieniu do zjawisk innych niż Zagłada. To właśnie pole badań, opisane przez Wolskiego także w kolejnej książce za pomocą formuły „pisarstwo Zagłady jako naukowa dziedzina”, ${ }^{37}$, a przede wszystkim argumentacja dotycząca wyboru takiego właśnie opisu (w Tadeuszu Borowskim - Primo Levim... autor wywodzi ją z konstruktywizmu ${ }^{38}$ ), wymagałoby pogłębienia i uszczegółowienia.

Chcąc podsumować drugi przykład agonizmu, należałoby wskazać na zasadnicze podobieństwa łączące go z pierwszym przykładem. Także i tutaj siła indywidualnych przekonań na temat tego, jak można wyobrażać sobie pisanie

${ }^{36} \mathrm{P}$. Wolski, O intencjach, przypisach i przy-pisywaniu (w odpowiedzi Danucie Szajnert), „Teksty Drugie” 2016, nr 6, s. 443.

${ }^{37}$ P. Wolski, Wstręt i Zagłada. Nowoczesność Tadeusza Borowskiego, Kraków-Budapeszt-Syrakuzy 2018, s. 18.

${ }^{38}$ P. Wolski, Tadeusz Borowski - Primo Levi..., s. 322. 
o Zagładzie, pochodzi z przekonań zbiorowych. Aby uzasadnić swoją teorię, autor musi wejść $\mathrm{z}$ innymi badaczami w drobne, mikrologiczne spory. Podobnie jak wcześniej, efektem takiej taktyki staje się coś wręcz przeciwnego niż prezentacja własnych poglądów. W myśl teorii Mouffe pluralizm, do którego mają prowadzić dyskusje, nie polega na odbieraniu sobie głosu kosztem utrzymania stanu fałszywie pojętej demokracji w nauce. Własny głos powinien być na tyle mocny, aby potrafił prowadzić spory, zmieniać stanowiska, odpierać ataki, ale też rozumieć, że układ sił nie może być stabilny i wręcz wymusza na pozostałych uczestnikach gry zachowania kontrhegemoniczne.

\section{Afirmacja przeciw agonizmowi}

We współczesnej myśli zachodniej istnieje nurt badań zmierzający do przezwyciężenia koncepcji opartych na takich kategoriach jak agon czy polemika, które utożsamiane są przede wszystkim ze zmierzchem filozofii postmodernistycznej, skoncentrowanej wokół nieobecności, pustki, melancholii i żałoby. Reprezentująca go Ewa Domańska twierdzi, że ideą przewodnią humanistyki afirmatywnej, o której tu mowa, jest myślenie o przyszłości i czynienie z tego strategii, która ma nie tyle dać możliwość unikania konfrontacji z bieżącą polityką, niezmiennie dopuszczającą możliwość ludobójstw, śmierci i negatywności, ile powinna przynieść nową perspektywę - poruszania się w „kierunku tego, co pozytywne”39.

$\mathrm{O}$ ile agon, jak wynika $\mathrm{z}$ analizy dwu przykładów, niekoniecznie wzmacnia podmiot dyskursu, częściej prowadząc do pozornej demonstracji siły i okopywania się we własnej słabości ${ }^{40}$, o tyle celem humanistyki afirmatywnej jest właśnie

wzmocnienie podmiotu i wspólnoty (złożonej z ludzkich i nie-ludzkich person). Pojęcie sprawczości i jego odpowiednie rozumienie jest tutaj kluczowe. Podmiot jest w tym projekcie ujmowany jako sprawca, który ma potencjalność, by działać i wprowadzać zmiany. Może nim być zarówno człowiek, jak i zwierzę, roślina lub rzecz ${ }^{41}$.

Niezależnie od źródeł europejskiego literaturoznawstwa dotyczącego Zagłady, zrośniętych z kulturą sporu, nieagonistyczny charakter ich polskiej reprezentacji wcale nie musi być wadą. Przeciwnie, powinno się tak je projektować i prowadzić, by szukać odnowienia podstaw europejskiej humanistyki w takich kategoriach

${ }^{39}$ Ch. Maser, Nowa wizja lasu, tłum. J. P. Listwan, J. Majewski, Bystra k. Bielska Białej 2003, s. 154.

${ }^{40}$ Co istotne, źródłosłów pojęcia ,agon” wiąże się z agonią, umieraniem: K. E. Carr, What is an agon? Greek philosophy, „Quatr.us Study Guides” 2017, https://quatr.us/greeks/agon-greekphilosophy.htm (d.d. 18.02.2019). Cf. W. Kopaliński, Stownik wyrazów obcych i zwrotów obcojęzycznych z almanachem. Część pierwsza od A do M (mi-parti), Warszawa 2007, s. 18.

${ }^{41}$ E. Domańska, Humanistyka afirmatywna: wtadza i płeć po Butler i Foucaulcie, „Kultura Współczesna” 2014, nr 4, s. 128. 
jak „życie”, „wspólnota” i „współdziałanie”, co może (ale nie musi) skutkować odrodzeniem idei zbiorowych pomysłów i zespołów. Przede wszystkim jednak należałoby wyjść poza granice dosłownie rozumianego postmodernizmu ${ }^{42} \mathrm{ku}$ posthumanistyce, która z kolei wymaga rozszerzenia horyzontu badań o wiele innych dyscyplin niż samo literaturoznawstwo. Przykładem „wertykalnie” prowadzonych studiów, zachowujących z jednej strony afirmatywność, a z drugiej dalekich od idei agonu, mogą być prace zrodzone z ducha teorii afektu czy refleksji nad przedmiotem i zwierzętami ${ }^{43}$. Słowem-kluczem wydaje się w nich nie „agon”, ale „więź” (ang. bond). Nie traktowałabym go jako konkurencji dla przedstawionych we wstępie założeń teorii Mouffe. Proponuję w nim widzieć raczej ich przezwyciężenie i uzupełnienie. Niedostatki w myśleniu o literaturze Zagłady w kategoriach wspólnoty i więzi muszą bowiem prowadzić do wyłonienia się tradycyjnych i bezużytecznych postaw, takich jak zdobycie dominacji nad innymi (Grynberg), skupienie się na inkluzywnych kategoriach charakterystycznych dla poststrukturalizmu (Wolski) czy autonomizacja i usztywnienie wiedzy.

Agon nie musi zniknąć ze współczesnego słownika pojęć. Powinien jednak, jako kategoria związana $\mathrm{z}$ władzą i śmiercią, zostać poddany krytyce, w tym także krytyce genderowej, weryfikującej związek postaw agonicznych z działalnością mężczyzn. Przywrócenie agonu dzisiejszej humanistyce jest jak najbardziej możliwe, chociażby w odniesieniu do zachowań tworzących wspólnotę i edukujących jednostki. To, czego należy unikać, łączy się natomiast z postawami zmierzającymi do supremacji. Agoniczne konteksty afirmacji warto zachować.

\section{Bibliografia}

Adorno, Theodor, Negative Dialektik. Meditationen zur Metaphysik, Frankfurt 1966. Bloom, Harold, Lęk przed wpływem. Teoria poezji, tłum. A. Bielik-Robson, M. Szuster, Kraków 2002.

Borowski, Tadeusz, Krytyka, w: idem, Pisma w czterech tomach, red. T. Drewnowski, J. Szczęsna, S. Buryła, Kraków 2005.

Buryła, Sławomir, Wokót Zagłady. Szkice o literaturze Holokaustu, Kraków 2016.

Carr, Karen E., What is an agon? Greek philosophy, „Quatr.us Study Guides” 2017, https://quatr.us/greeks/agon-greek-philosophy.htm (d.d. 18.02.2019).

Dobrosielski, Paweł, Spory o Grossa. Polskie problemy z pamięcia o Żydach, Warszawa 2017.

Domańska, Ewa, Humanistyka afirmatywna: wtadza i płeć po Butler i Foucaulcie, „Kultura Współczesna” 2014, nr 4.

${ }^{42}$ Ibidem, s. 119-122.

${ }^{43}$ Chodzi m.in. o artykuły i monografie Jacka Leociaka o śmieciach, Bożeny Shallcross o rzeczach, Agnieszki Daukszy o afektach oraz Anity Jarzyny i Piotra Krupińskiego o zwierzętach. 
Felstiner, John, Paul Celan. Poeta, ocalony, Żyd, tłum. M. Tomal, M. Tomal, red. P. Paziński, Budapeszt 2010.

Forecki, Piotr, Po Jedwabnem. Anatomia pamięci funkcjonalnej, Warszawa 2018.

Grynberg, Henryk, Mój krytyk za dużo wyczytat, „Odra” 2002, nr 6.

Grynberg, Henryk, Pokolenie Szoa, „Odra” 2002, nr 4.

Grynberg, Henryk, Pamiętnik, Warszawa 2011.

Januszkiewicz, Michał, Horyzonty nihilizmu. Gombrowicz, Borowski, Różewicz, Poznań 2009.

Kopaliński, Władysław, Słownik wyrazów obcych i zwrotów obcojęzycznych z almanachem. Część pierwsza od A do M (mi-parti), Warszawa 2007.

Krupa, Bartłomiej, Opowiedzieć Zagładę. Polska proza i historiografia wobec Holocaustu (1987-2003), Kraków 2013.

Kuczyńska-Koschany, Katarzyna, Wsje poety Żydy. Antytotalitarne gesty poetyckie i kreacyjne wobec Zagłady oraz innych doświadczeń granicznych, Poznań 2013.

Leociak, Jacek, Grynberg niebanalnie o Głowińskim, „Odra” 2002, nr 4.

Mach, Anna, Świadkowie świadectw. Postpamięć Zagłady w polskiej literaturze najnowszej, Warszawa-Toruń 2016.

Maser, Chris, Nowa wizja lasu, tłum. J. P. Listwan, J. Majewski, Bystra k. Bielska Białej 2003.

Mouffe, Chantal, Agonistyka. Polityczne myślenie o świecie, tłum. B. Szelewa, Warszawa 2015.

Muchowski, Jakub, Polityka pisarstwa historycznego, Warszawa-Toruń 2015.

Nowicka-Franczak, Magdalena, Spór o książki Jana Tomasza Grossa, Warszawa 2017.

Szajnert, Danuta, O prze-pisywaniu, „Teksty Drugie” 2016, nr 1.

Tokarska-Bakir, Joanna, Skandalista Henryk Grynberg, „ResPublica Nowa” 2003, nr 6.

Tokarska-Bakir, Joanna, Nowa polska szkoła historyczna albo sabat antypolskich czarownic $w$ Paryżu, https://www.academia.edu/38512291/Nowa_polska_szko\%C5\%82a historyczna_albo_sabat_antypolskich_czarownic_w_Pary\%C5\%BCu (d.d.16.02.2019).

Tomczok, Marta, Czyja dzisiaj jest Zagłada? Retoryka - ideologia - popkultura, Warszawa 2017.

Ubertowska, Aleksandra, Pawet Wolski, Tadeusz Borowski - Primo Levi. Przepisywanie literatury Holocaustu, Wydawnictwo IBL PAN, Warszawa 2013, 362 s., „Zagłada Żydów. Studia i Materiały” 2015, nr 11.

White, Hayden, Poetyka pisarstwa historycznego, red. E. Domańska, M. Wilczyński, Kraków 2000.

White, Hayden, Proza historyczna, red. E. Domańska, Kraków 2009.

White, Hayden, Przeszłość praktyczna, red. E. Domańska, Kraków 2014.

Wolski, Paweł, Tadeusz Borowski - Primo Levi. Prze-pisywanie literatury Holocaustu, Warszawa 2013.

Wolski, Paweł, O intencjach, przypisach i przy-pisywaniu (w odpowiedzi Danucie Szajnert), ,Teksty Drugie” 2016, nr 6.

Wolski, Paweł, Wstręt i Zagłada. Nowoczesność Tadeusza Borowskiego, Kraków-Budapeszt-Syrakuzy 2018. 
MARTA ToMczoK, badaczka Zagłady i jej odniesień kulturowych, adiunkt na Wydziale Filologicznym Uniwersytetu Śląskiego, redaktor naczelna rocznika „Narracje o Zagładzie”. Autorka książek: Trofea wyobraźni. O prozie Leo Lipskiego (2011), Metonimie Zagłady. O polskiej prozie lat 1987-2012 (2013), Czyja dzisiaj jest Zagłada? Retoryka - ideologia - popkultura (2017). Artykuły i recenzje publikowała m.in. w „Historyce Studiach Metodologicznych”, „Tekstach Drugich”, „Pamiętniku Literackim”, „Ruchu Literackim”, „Porównaniach”, „Poznańskich Studiach Polonistycznych”, „Poznańskich Studiach Slawistycznych”, „Zagadnieniach Rodzajów Literackich”, „Zagładzie Żydów. Studiach i Materiałach”. Współpracuje z miesięcznikiem „Nowe Książki”. Interesuje się wpływem nowych metodologii na studia o Zagładzie i innych ludobójstwach, refleksją krytyczną nad estetykami uznanymi za minione (postmodernizm), nowym animizmem oraz historią środowiskową węgla. 